\title{
Physical and Chemical Conditions of Bayur Bay Waters on the East and West Season
}

\author{
Ulung Jantama Wisha*, Try Al Tanto and Ilham \\ Research Institute for Coastal Resources and Vulnerability, Ministry of Marine Affairs and Fisheries \\ Jl. Raya Padang-Painan KM. 16, Bungus, Padang - Sumatera Barat 25245 \\ Email: ulungjantama@gmail.com
}

\begin{abstract}
Physical construction of Bayur bay coastal area as a port was followed by a variety of environmental issues, both physical degradation of the natural environment, biology reduction and an increase in social problems, directly affect to water quality decreasing in the coastal Bayur Bay. This study aims to determine the concentration distribution of physical and chemical parameters and their influence to water conditions on the east and west season. The method used is descriptive method (data taken by in situ and laboratory analysis), determining the location of sampling points based on purposive sampling method and tide prediction by NAOtide software. The results of field survey and laboratory measurements were analysed using statistical method. The speed of sea currents on the east season ranged from 3,48 to 24,9 cm.s.-1, while in the West season flow rate ranged from 1,4 to $57,7 \mathrm{~cm} . \mathrm{s}^{-1}$. Rainfall in East season ranged from 0-45 mmand The intensity of rainfall in West Season ranged from 0-30 $\mathrm{mm}$. Sea-surface temperatures in the Eastern season range between $26,2-31.5{ }^{\circ} \mathrm{C}$, while in the west season SST range from 24,3 to $30,5^{\circ} \mathrm{C}$. Dissolve oxygen concentration in the east season range from 4,3 to 6,1 mg. $L^{-1}$, while the west monsoon conditions range from 4,1 to $6,4 \mathrm{mg} \cdot \mathrm{L}^{-1}$. The $\mathrm{pH}$ values ranged from 7,4 to $8,1 \mathrm{in}$ the Eastern season and ranged from 7,12 to 8,27 in the West season. Bayur Bay water quality conditions is not much different from its value range on the west and east season and influencing each other.
\end{abstract}

Keywords: Bayur Bay, east and west seasons, SST

\section{Introduction}

Like the other major cities in Indonesia, Padang physical development was followed by a variety of environmental issues especially for Bayur Bay area, both physical degradation of the natural environment, biology reduction and increase in social problems. Accumulation of environmental problems caused by the disposal of various types of solid and liquid waste directly into the environment, as well as the limited capacity of environmental facilities and infrastructure services, particularly infrastructure drainage and environmental sanitation (Hong, 2012).

Utilization of Bayur Bay area is quite diverse including industry, hospitals, port fishing boats and passenger ships as well as a recreational area, especially since the increasing development in coastal areas helped reduce water quality in the Bayur Bay area. Judging from the density of community activities around the estuaries and coastal areas causing the water to become cloudy tend to brown accompanied by the unpleasant aroma and high sedimentation rate (Bapedalda Kota Padang, 2004). Sea Surface Temperature of Bayur Bay directly sensitive to processes that occurred in the Indian Ocean, such as the phenomenon of the Indian Ocean Dipole and ENSO have an impact on rainfall in the season occurred in Indonesia and has a lot of effect to another water parameter, and results from the interaction between the atmosphere and the ocean and affect the transport mechanism (upwelling and downwelling) on the Bayur Bay, Padang coast (Yamagata et al., 2002).

The pollutant degradation and other various processes happened after entering the water. Such processes are influenced by the hydrodynamic conditions such as mixing that usually occurs in the estuary and around the beach, the tide and the large streams that enter have a major role in the process of mixing can eventually dissolve contaminants that enter to the Bayur Bay. changes in environmental conditions of water causes many effects, such as ocean acidification which occurs due to an increase in temperature accompanied by an increase in waste disposal into the sea, that changes in sea temperatures, unstable cause dissolved oxygen conditions were unstable too (Putri, 2007).

From the explanation above is very important to monitor water quality in the Bayur bay which is the centre of sea transportation in the city field, and 
need to be investigated climate and season change impacts to changing water and biotic conditions in the bay waters sustainably. The purpose of this study was to determine the distribution of physical and chemical parameters in the waters and its influence on water conditions on the east and west season.

\section{Materials and Methods}

This research was conducted in two phases: field sampling and laboratory analysis stage. The method used is descriptive method. Determining the location of the sampling points based on purposive sampling method. Field studies were conducted during two different season periods i.e. west and east. Sampling were done at 11 stations spread along the Bayur Bay, which represents the area of the river, estuary and intertidal zone to the area of breaking waves (Figure 1.).

According Sugiyanto and Nugroho (2007) the tidal type in Bayur Bay waters is mixed semidiurnal. It can be seen also from the results predicted tidal in Bayur Bay waters in Figure 2 for the month of June and Figure 3a for the month of December 2015. Tidal prediction obtained by using NAOtide software with coordinate $100,38089 \mathrm{E}$ and $-1, .0080 \mathrm{~S}$. At the time the survey was conducted in June, Bayur Bay having two times for high tide, at around $00.00 \mathrm{pm}$ and $11.00 \mathrm{am}$ and the low tide occurs twice around $06.00 \mathrm{pm}$ and $17.00 \mathrm{pm}$. Samples were taken at low tide on tidal conditions towards each season.Precipitation data obtained from the recording AWS (Automatic Weather Station) in Muaro Anai, for analysis by the weather conditions at the time of the study.

The data used in this study consisted of primary data, speed and direction of currents, physical parameters (temperature) and chemical parameters (Dissolve Oxygen (DO) and $\mathrm{pH}$ ) as well as secondary data including RBI Indonesia Map and Google Earth imagery GeoEye 2015. Some parameters such as temperature and $\mathrm{pH}$ were measured in situ by using TOA DKK water quality Checker, and DO parameters analysed in the laboratory Research and Standardization Industry Padang. Water sampling is done by using a Van dorn Water sampler in the surface layer, and then composited and stored in a cool box.

Winkler titration method by means generally used to determine the levels of dissolved oxygen based on iodometry titration. Samples to be analysed first added a solution of $\mathrm{MnCl}_{2}$ den $\mathrm{NaOH}$ $\mathrm{KI}$, so it will happen $\mathrm{MnO}_{2}$ precipitate. By adding $\mathrm{H}_{2} \mathrm{SO}_{4}$ and $\mathrm{HCl}$ then deposits that occur

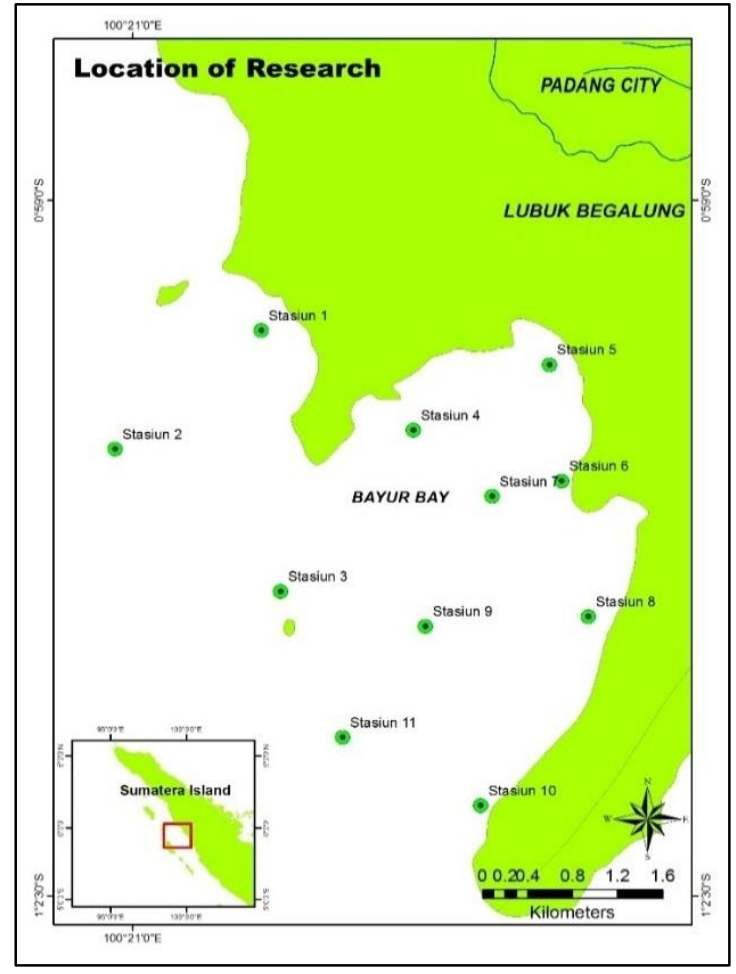

Figure 1. Location of 11 sampling stations 


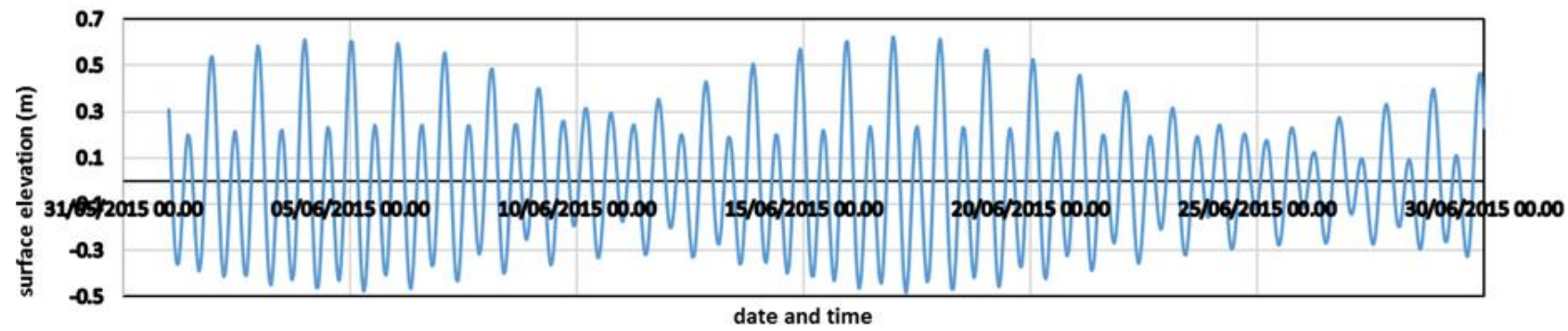

Figure 2. Tide Prediction for 1-30 June 2015

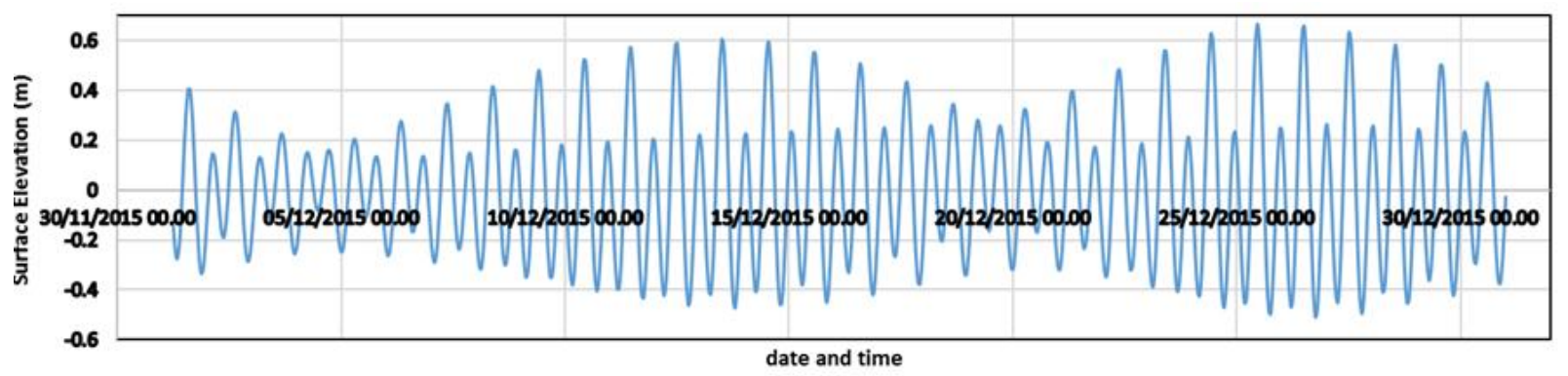

Figure 3. Tide Prediction for 1-31 December 2015

will dissolve back and will also free molecular iodine $\left(\mathrm{I}_{2}\right)$ which is equivalent to dissolved oxygen. Liberated iodine is then titrated with a standard solution of sodium thiosulfate $\left(\mathrm{Na}_{2} \mathrm{~S}_{2} \mathrm{O}_{3}\right)$ and using an indicator solution of starch (starch). To find how much titrant volume with read-scale reduction in titrant and enter the formula below:

$$
\mathrm{DO}\left(\mathrm{mg} \cdot \mathrm{L}^{-1}\right)=\frac{m L \text { titrant } \times N \text { titrant } \times 8 \times 1000}{m L \text { Sample }}
$$

Measurements of ocean currents were made by Euler principle. Currents velocity was measured by using a Floating Drogue with a length of rope five meters, the maximum time limit is 5 minutes and 50 $\mathrm{cm}$ tall ships, and direction of currents seen using a compass. The results of in situ current measurements are recorded and processed spatially using ArcGIS 10.3 software.

\section{Results and Discussion}

The effect of weather is very significant to water conditions, especially temperature, $\mathrm{pH}$ and directly affect dissolution process oxygen in the sea. rainfall in June ranged from $0-45 \mathrm{~mm}$. The results of physical and chemical parametersof Padang waters in June/east monsoon and in December/west monsoon were presented in Tabel 1 and 2. The results of the currents speed and direction in situ measurements is shown in Figure $4 a$ for currents conditions in East season and Figure $4 \mathrm{~b}$ for the Currents conditions on west season. The ocean currents during east or dry season were ranged from 3,48 to $24,9 \mathrm{~cm} . \mathrm{s}^{-1}$. The dominant of currents direction was towards the mainland. In the west season or rainy season flow velocity ranged from 1,4 to $57,7 \mathrm{~cm} . \mathrm{s}^{-1}$ and the direction of the dominant Currents move away from the mainland. In Western of Sumatera Island, currents velocity including strong current pace for dealing directly with the Indian Ocean, directly Bayur Bay waters affected by processes that occurred in the Indian Ocean.

According Sugiyanto and Anugroho (2007), the average current speed in Bayur Bay waters during the east season was $14 \mathrm{~cm} . \mathrm{s}^{-1}$ with the dominant direction towards north and northwest. The highest current speed was $23 \mathrm{~cm} . \mathrm{s}^{-1}$ to the northeast, while on the west season, the dominance of the current to the south to the north. Although some current movement towards the southwest, the maximum currents velocity was $22 \mathrm{~cm} . \mathrm{s}^{-1}$ and the average current speed was $13 \mathrm{~cm} . \mathrm{s}^{-1}$. The results of previous studies by Fajri et al. (2012) showed that the current speeds of same location were ranged

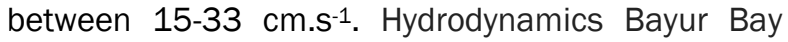
waters also influence the distribution of the concentration of water quality parameters, including temperature, $\mathrm{pH}$ and dissolved oxygen, especially flows generated by tidal change. Transport that happened, especially for areas estuaries and bays causing physical and chemical parameters of sea water distributed in accordance with 
ILMU KELAUTAN March 2017 Vol 22(1):15-24

Table 1. Description of the data statistics physical and chemical parameters June 2015

\begin{tabular}{lclllllll}
\hline \multicolumn{1}{c}{ Parameters } & Mean & $\begin{array}{c}\text { Standard } \\
\text { Error }\end{array}$ & Median & Mode & $\begin{array}{c}\text { Standard } \\
\text { Deviation }\end{array}$ & Minimum & Maximum & $\mathrm{N}$ \\
\hline temperature & 29,39397 & 0,222916 & 30,2 & 30,5 & 1,697678 & 26,2 & 31,6 & 58 \\
\hline Do & 6,032241 & 0,0947 & 5,955 & 6,8 & 0,721217 & 4,3 & 7,6 & 58 \\
\hline pH & 7,864655 & 0,034798 & 8,01 & 7,4 & 0,285572 & 7,4 & 8,2 & 58 \\
\hline
\end{tabular}

Table 2. Description of the data statistics physical and chemical parameters December 2015

\begin{tabular}{lllllllll}
\hline \multicolumn{1}{c}{ Parameter } & \multicolumn{1}{c}{ Mean } & $\begin{array}{c}\text { Standard } \\
\text { Error }\end{array}$ & Median & Mode & $\begin{array}{c}\text { Standard } \\
\text { Deviation }\end{array}$ & Minimum & Maximum & $N$ \\
\hline Temperature & 29,28158 & 0.23871 & 30 & 30 & 1,471505 & 25,2 & 30,7 & 38 \\
\hline Do & 5,56 & 0.08871 & 5,66 & 5,72 & 0,425441 & 4,11 & 6,43 & 23 \\
\hline pH & 8,04304 & 0.0549 & 8,12 & 8,11 & 0,263291 & 7,12 & 8,28 & 23 \\
\hline
\end{tabular}

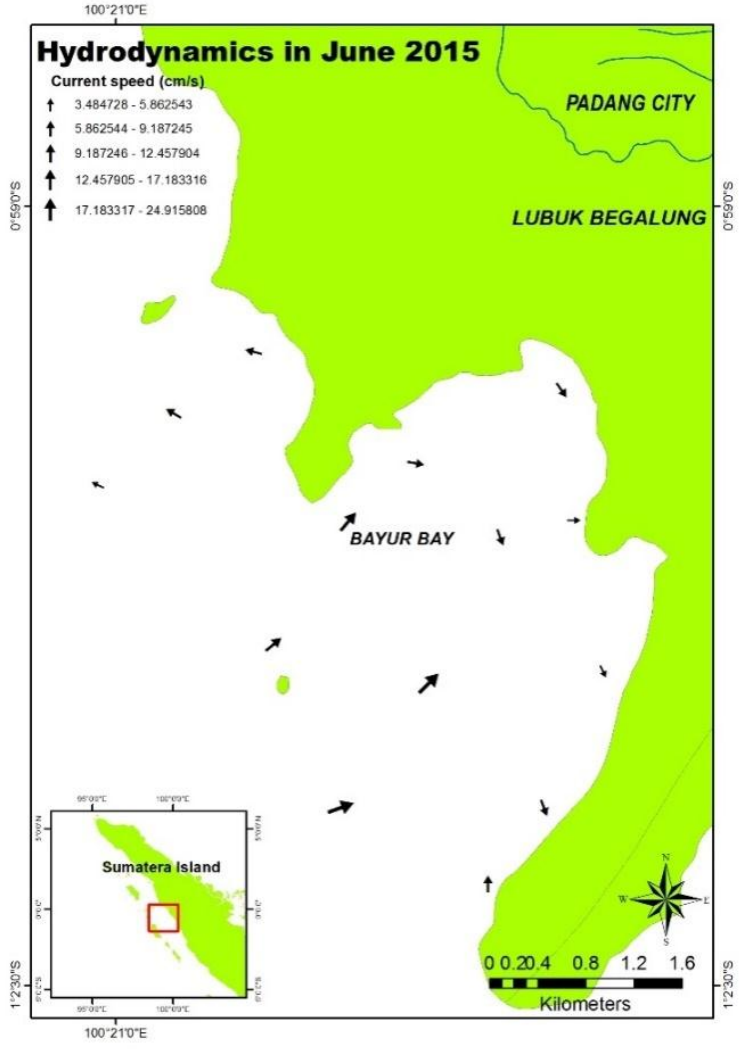

(a)

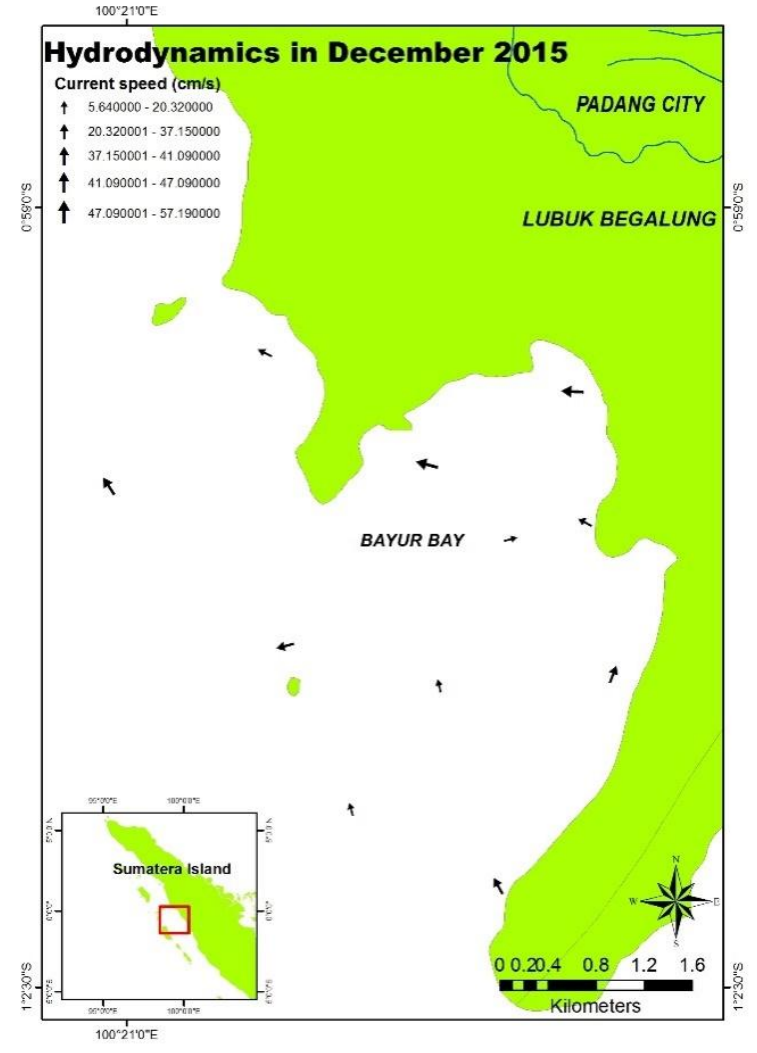

(b)

Figure 4. Circulation of currents, (a) East season; (b) West season at research location

the direction of movement of the tidal currents. Circulation of flow patterns in the east season influence on the distribution of physical and chemical parameters in Bayur Bay waters, including in the distribution of SST (sea surface temperature), mixing and turbulence as well as the process of upwelling and downwelling which also relates to the process (IOD) Indian Ocean Dipole and ENSO (EI nino south oscillation).
The effect of weather is very significant to water conditions, especially temperature, $\mathrm{pH}$ and directly influence to dissolution process oxygen in the sea. The rainfall during June were ranged from 0$45 \mathrm{~mm}$ (Figure 5.). Changes in climate and weather conditions have direct effect on the condition ofwaters in the Gulf Bayur, especially sea surface temperature fluctuating, it is not free from the influence of the Indian Ocean dipole, resulting in 


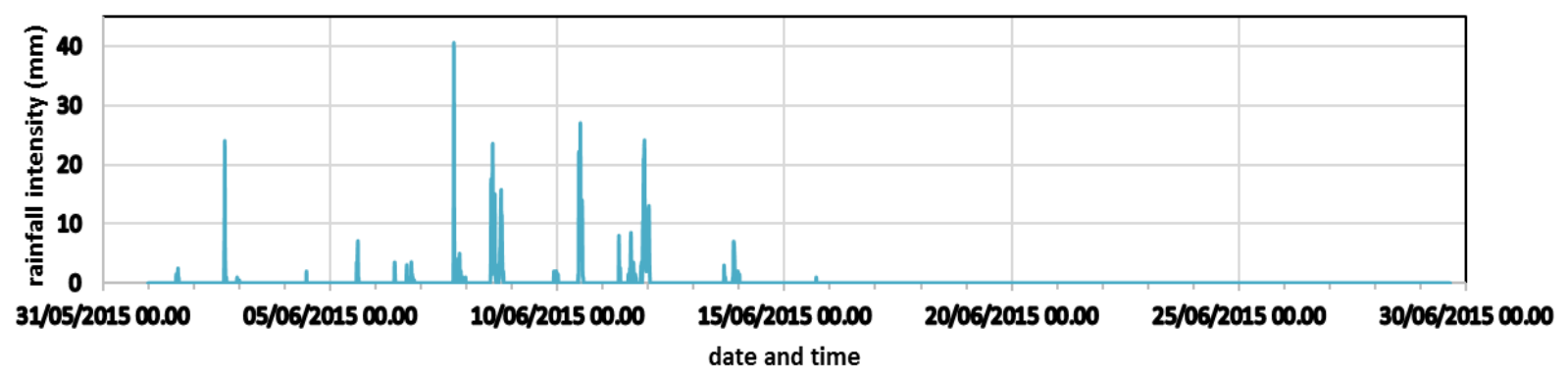

Figure 5. Rainfall Intensity on East Season

weather and SST anomalies in the region of West Sumatera. Ashok et al. (2003) states that the change IndianOcean sustainably dipole anomalies affect the weather on western Sumatra island and southern parts of Java island.

The intensity of rainfall in December ranged from 0-30 $\mathrm{mm}$ (Figure 6.), lower than in June but rains occurred in December more evenly almost a full month, during the rainy sea surface temperatures become colder so the oxygenisdissolvedquicker, and cause the concentration of oxygen in the surface becomes high. The decline in sea surface temperatures also impact on the acidity of the sea, so the sea water tends to be more acid.

Sea-surface temperatures in the Eastern season ranged between $26,2-31,6^{\circ} \mathrm{C}$ with the highest temperature being in station 8 , while in the west monsoon SST ranged from 24,3 to $30,5^{\circ} \mathrm{C}$ with a maximum temperature almost evenly across the waters desert region and a breaking wave in the Bayur Bay region. SST conditions in the west and east season is also influenced by the phenomenon of Indian Ocean Dipole (IOD) and El- Nino South Oscillation (ENSO), which affects the climate and weather conditions in the Indian Ocean region so that the temperature of the surface is frequent anomalies due the phenomenon. Abraham et al. (2007) said that the conditions relating to SST studied IOD events and also the Asian monsoon and the ENSO system that contribute to the occurrence of positive IOD, Kwiatkowski et al. (2015) states that the value of SST at the time of the positive IOD range between $27-29^{\circ} \mathrm{C}$ and at the time of the negative IOD SST ranged from 28,3 to $30,5^{\circ} \mathrm{C}$. IOD is basically a picture of temperature anomalies in the Indian Ocean region and also indicates the influence of ENSO SST Condition (Ashok et al., 2003). The annual SST variations are phase locked to the cycle of seasons, mature phase of positive IOD always occur at the southeast monsoon season ( $\mathrm{Du}$ and Tanggong, 2008).

The average sea surface temperature in East season (Table 1.) is greater than during West season (Table 2.). It is caused by the rain in west season, so waters tends to lower the temperature, but the sea surface temperature in the west season has a maximum value is very high, it is associated with high evaporation during the west season. According to Fadholi (2013) the changeing of wind and ocean surface temperature resembles the ENSO phenomenon, IOD conditions affect to convection in the western part of Sumatera Island and regional rainfall.

The concentration of dissolved oxygen in the east season ranged from 4,3 to $6,8 \mathrm{mg} \cdot \mathrm{L}^{-1}$ while the west season ranged from 4,1 to $6,4 \mathrm{mg}$.L-1 (Figure 8.). The range value of $D O$ in the second season was not too different, so that the water conditions are relatively stable. On the surface concentration of DO is affected by the diffusion of oxygen from the air and the rate of photosynthesis by marine plants such as mangroves, sea grass and seaweed. According to Sanusi (2004) the process of diffusion of oxygen from the air and photosynthesis is a causative factor DO value the larger and relatively stable in the surface layers, as is generally tropical marine waters a natural phenomenon. Standard criteria for DO concentration in waters ranged between 4-6 mg.L-1 (Partowijoto, 2006).

According to Putri (2010) the distribution of dissolved oxygen in the Padang waters almost uniform (range 3,87 to $6,7 \mathrm{mg} \cdot \mathrm{L}^{-1}$ ), the dissolved oxygen in the surrounding rivers and estuaries is not eligible for the microbial life, and the critical level of dissolved oxygen is below $2 \mathrm{mg} . \mathrm{L}^{-1}$ called hypoxic conditions. If this continues, it may cause pressure on the organism (stress) and the waters became anoxic conditions that could lead to the death of biota (Clingan and Norton, 1987). Dissolve oxygen content in Bayur Bay waters ranged between 4-5 


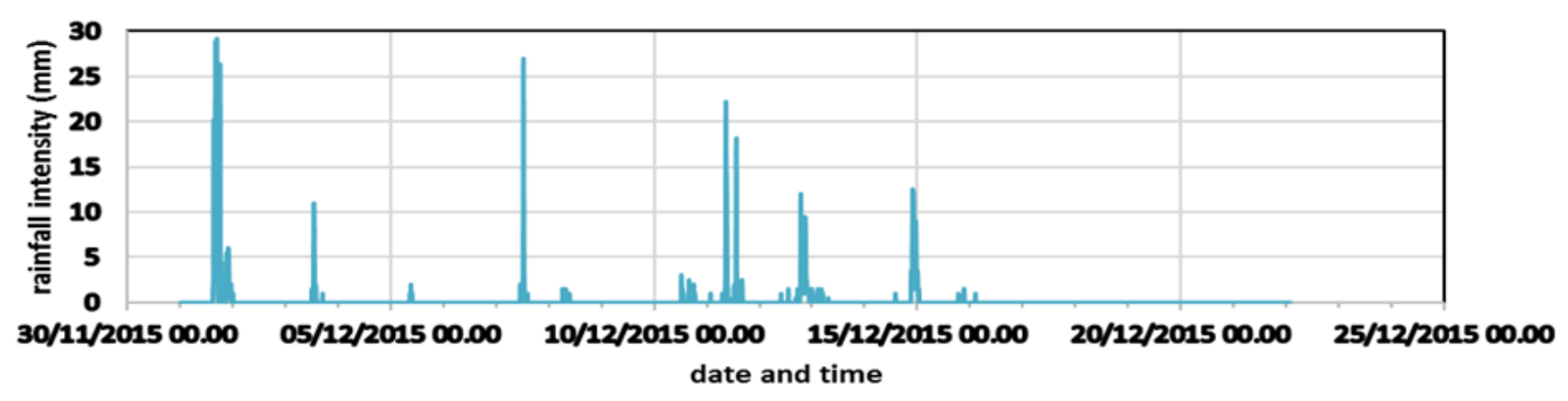

Figure 6. Rainfall Intensity on West Season

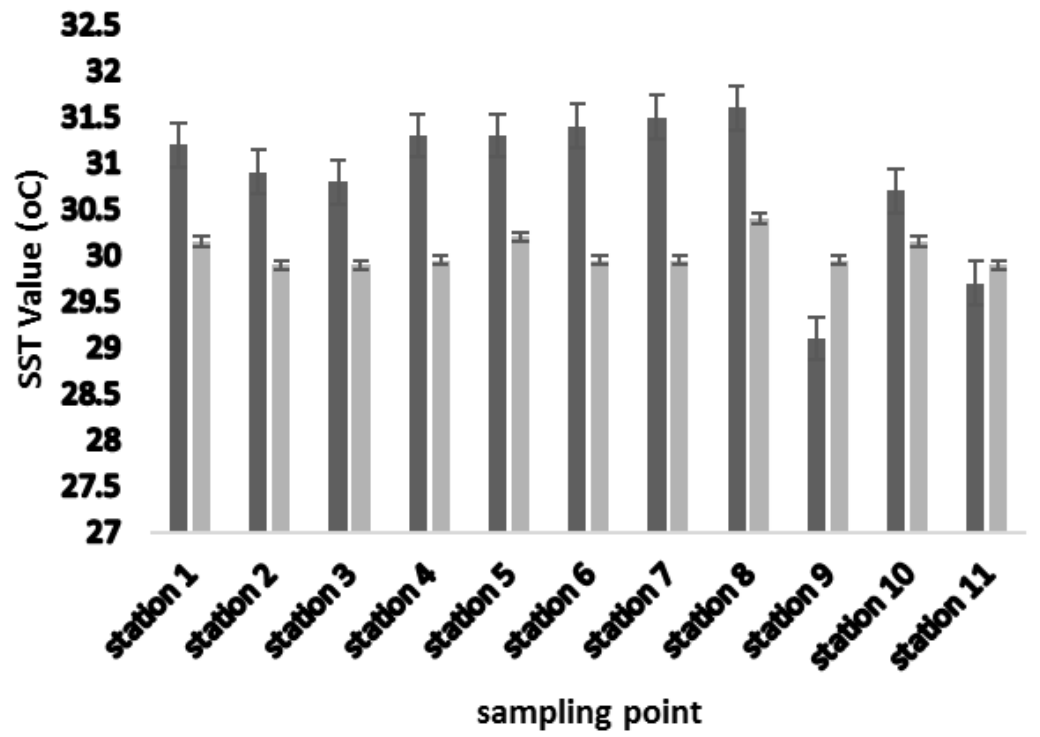

Figure 7. SST condition comparison of East and West Season Note : $\square$. June, $\square$ : Desember

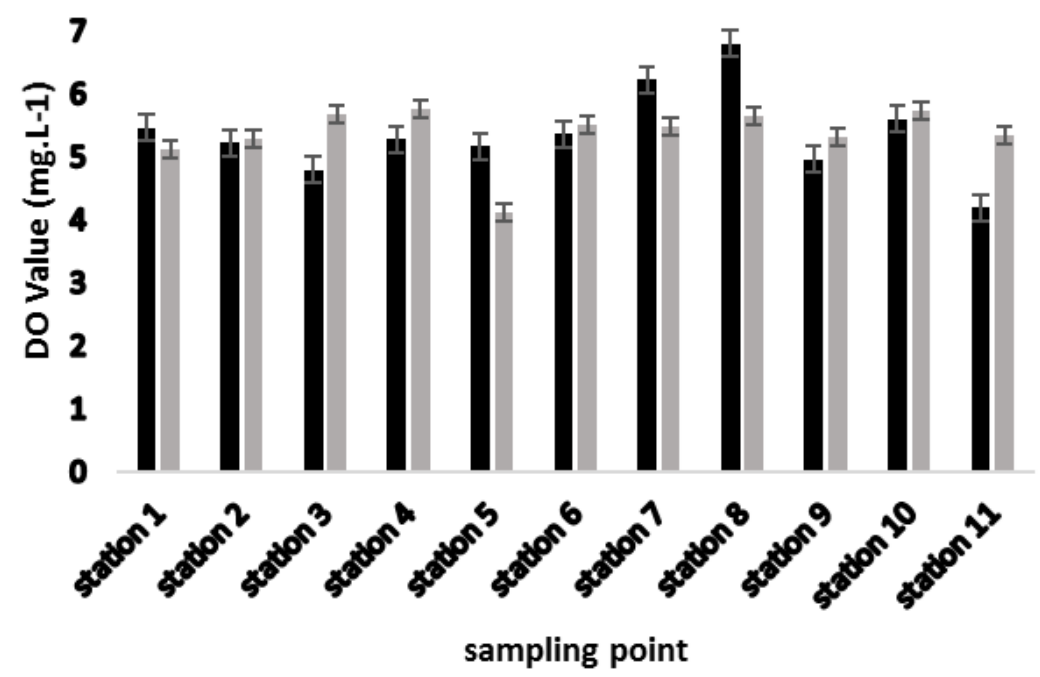

Figure 8. DO condition comparison on East and West Season Note : $\square$. June, $\square$ : Desember 
mg. $\mathrm{L}^{-1}$, the condition is already on the verge of establishedstandards, that is a minimum $4 \mathrm{mg} . \mathrm{L}^{-1}$, and this needs to be increased oversight, low dissolved oxygen caused by the many organic pollutants generated by industry in coastal areas of Bayur Bay (Kamal and Syahbuddin, 2003).

The $\mathrm{pH}$ values ranged from 7,4 to 8,1 in the East season and ranged from 7,12 to 8,27 in the West season (Figure 9.). High rainfall intensity causing acidity increased in the west season, the $\mathrm{pH}$ value in the both seasons is not too much different, which is about 7-8. According to Sanusi (2004) within a period of 2 different seasons $\mathrm{pH}$ distribution showed no significant differences, $\mathrm{pH}$ values stable buffer function shows good waters. The measurement results are more varied $\mathrm{pH}$ value ranged from 6,19 to 7,57 , the value of $\mathrm{pH}$ in estuary is 8,2 , it is still a decent value for marine organisms is 7 to 8,5 with 0,2 deviation from the natural $\mathrm{pH}$ sea water (Parsons et al., 1984; Putri 2010). According to Kamal and Syahbuddin (2003) in the waters Padang $\mathrm{pH}$ value ranged from 6.39 to 7.39 , the value is relatively normal. Previous research by the Dewata and Rahadian (2015) states that the $\mathrm{pH}$ value in Padang waters included Bayur bay in 2011 ranged from 6.8 to 8.3 , in $2012 \mathrm{pH}$ range is 6,83 to 7,8 , in 2013 ranged from 7,13 to 7.6, and in 2014 $\mathrm{pH}$ range is 6,5 to 7,15 . It appears that the value of ocean acidity has decreased each year, or in other words going seawater acidification, although the range is not too drastically different.
In east monsoon changes in temperature fluctuating effect on the condition of dissolved oxygen, shown in Figure 10 that the temperature is increasing proportional to the increasing concentration of dissolved oxygen in the surrounding Bayur bay, but it does not apply at all sampling locations, the general conditions of temperature influence the ability of the dissolved oxygen in the water and the release of oxygen from the water. According to Kamal and Syahbudin (2003), the temperature increases in proportion with the increase of oxygen in the water, and affect to other water quality parameters. Conditions that changes in temperature are likely to increase in eastern seasons also affect the acidity of sea water; increasing temperatures caused sea water to become acidic (Figure 11). This is caused by the effects of global warming is the increase in global temperatures which also increases the value of SST indirectly increase the leaching process carbon dioxide that sea water became an acid. According Natasasmita (2015) ocean acidification caused by rising atmospheric concentrations of carbon dioxide dissolved in seawater in large quantities and the dissolution process is also influenced by temperature.

In the west monsoon, rainfall during one month will led to SST decrease. Figure 12 showed that in every station has a difference in the effect of temperature on dissolved oxygen. There is other factor that affects the oxygen level in sea water i.e.

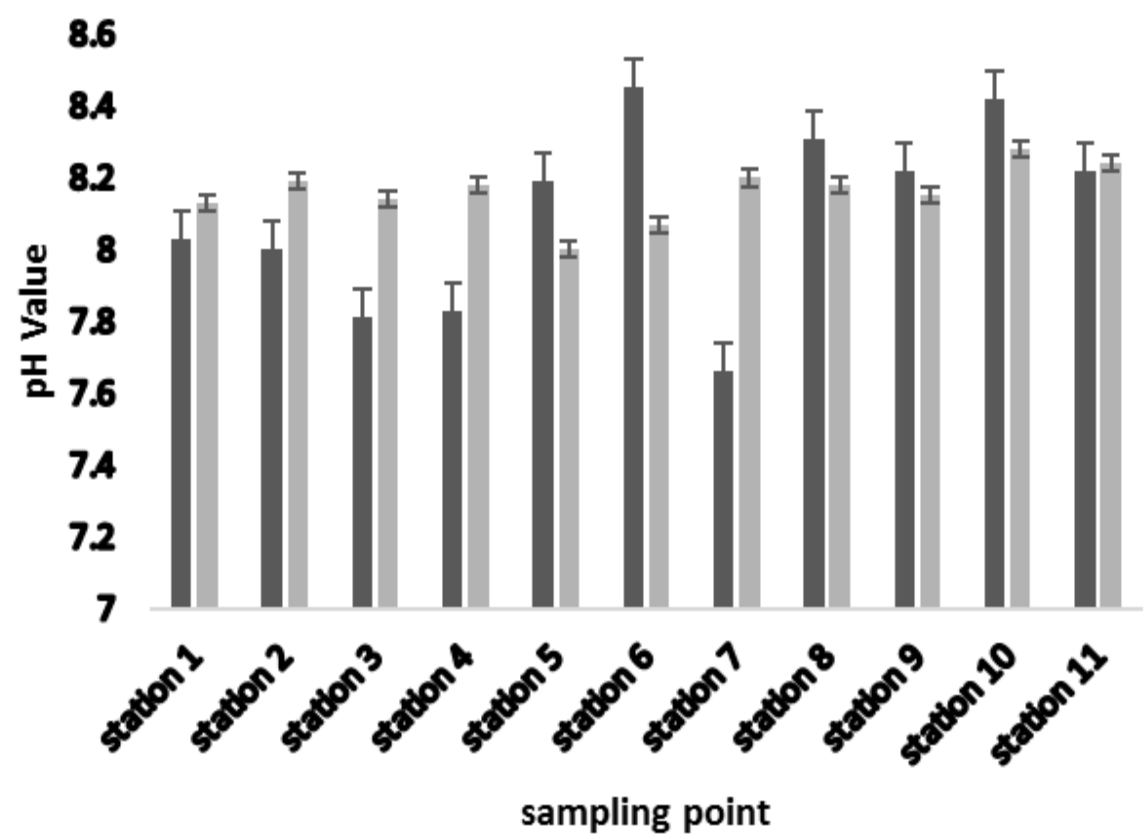

Figure 9. $\mathrm{pH}$ condition comparison during East and West Season Note. $\square$ : June, : Desember 


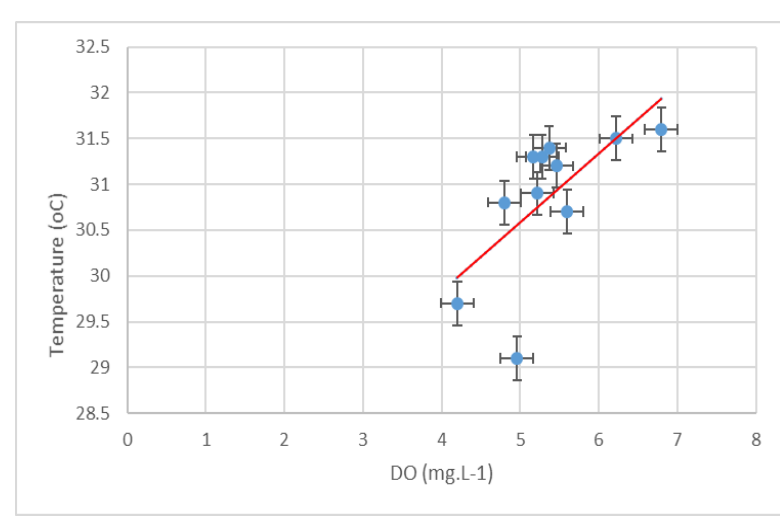

Figure 10. DO and temperature correlation on East season

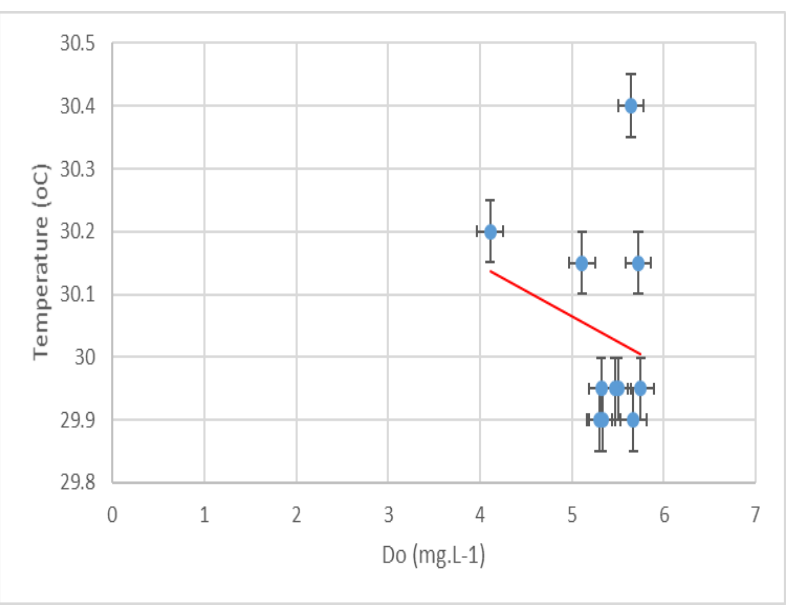

Figure 12. DO and temperature correlation on West season

salinity and the presence of the organism autotroph (phytoplankton). According Wisha et al. (2014) the value of dissolved oxygen is strongly influenced by water temperature, salinity and the presence of phytoplankton. Temperature relationship with $\mathrm{pH}$ is still the same (Figure 13.) i.e. increasing temperature will indirectly lower the $\mathrm{pH}$ value. The distribution of physical and chemical conditions of the waters can not be separated from the influence of hydrodynamic conditions of the sea, which is the main factor affecting the distribution of dissolvedsubstances and environmental conditions Bayur Bay waters. The presence of vessel traffic and port activity also affect that condition, but globally itsaffected by climate change and the weather was unstable and inconsistent by the Indian Ocean Dipole.

\section{Conclusion}

The value of water physical (temperature) and chemical (DO and $\mathrm{pH}$ ) conditions were not much

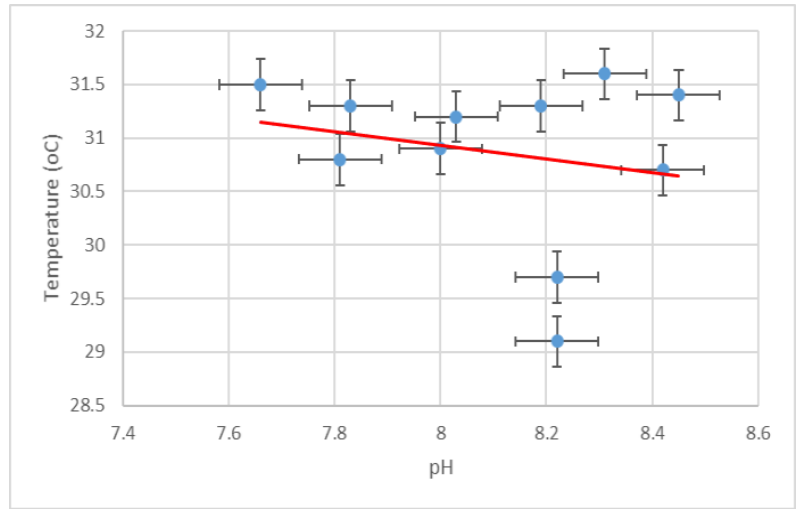

Figure 11. $\mathrm{pH}$ and temperature correlation on East season

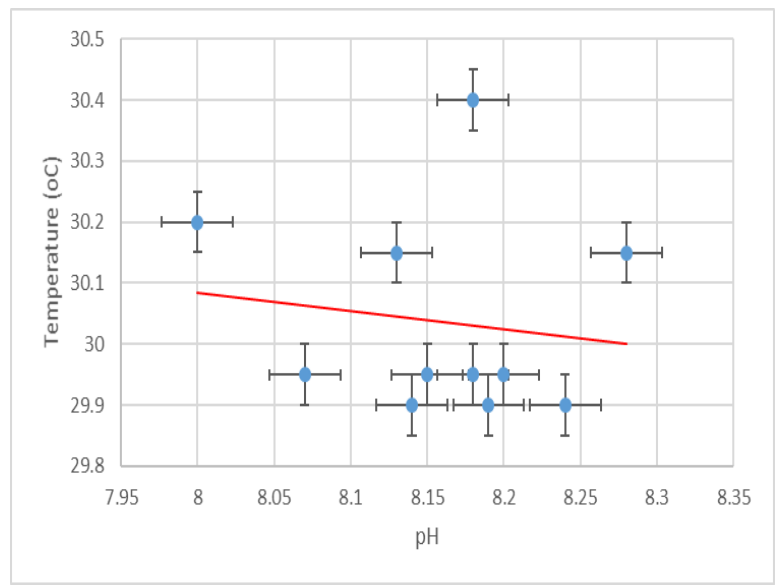

Figure 13. $\mathrm{pH}$ and temperature correlation on West season

different during the west and east seasons. In the west season conditions experienced SST anomaly for IOD and ENSO influences, the condition of dissolved oxygen in the surface water higher and more stable against changes season, due to the support by the diffusion of oxygen from the air and the process of photosynthesis by autotroph organisms. The $\mathrm{pH}$ value of the season is influenced by Western higher rainfall increases. In the east monsoon, temperature increases proportionally to the increase concentration of dissolved oxygen in the surrounding of Bayur Bay. Increasing temperatures also cause sea water to become acidic. In the west monsoon, rainfall evenly within one month led to the level of SST decrease, dissolve oxygen and $\mathrm{pH}$ conditions are stable same as condition in East Season.

\section{Acknowledgments}

Acknowledgements delivered to Research Institute for Coastal Resources and Vulnerability 
(LPSDKP) on DIPA APBN Research Budget 2015 in the Coastal of Padang City, and all those who helped in the implementation of this study.

\section{References}

Abraham, N.J., Gagan, M.K., Liu, Z., Hantoro, W.S, McCulloh, M.T. \& Suwargadi, B.W. 2007. Seasonal Characteristics of the Indian Ocean Dipole during the Holocene Epoch. J. Nature. 445(1): 849-853. doi:10.1038/nature05477.

Ashok, K., Zhaoyong, G. \& Toshio, Y. 2003. A Look at the Relationship between the ENSO and the Indian Ocean Dipole. J. Meteorological Soc. Japan. 81(1):41-56. doi: 10.2151/jmsj.81.41.

Bapeldalda (Badan Pengendalian Dampak Lingkungan Daerah) Kota Padang. 2004. Laporan Analisa Data Penelitian dan Pengujian Kualitas Air Permukaan di Kota Padang.

Cahyarini, S.Y. 2013. Seasonal Mean Variability of Coral-based Sea Surface Sanlinity from SImeulue, Mentawai, Bunaken and Bali. J. Geology. 8(3): 119-125. doi: 10.17014/ijog. v8i3.161.

Clingan, T. \& Norton, M.G. 1987. Wastes in Marine Environment. Congress of the United States. Office of Technology Assesment. Washington.

Dangnga, M.S., Tenriware, Abdullah, K. Jusoff, A.A. Muis \& M. Yusuf. 2013. Evaluation of Sero for Coastal Fishing in Sulawesi, Indonesia. J. World Appl.Sci. 26:77-81. doi: 0.5829/idosi.wasj. 2013.26.nrrdsi.26014.

Dewata, I. \& Rahadian, Z. 2015. Determination of pH-BOD-COD and Degradation in Batang Arau Watersheds at Padang City. J. Chemical and Pharmaceutical Res. 7(12):445-451. doi: JCPR2015.7.12.445451.

Du, Y. \& Tanggong, Q. 2008. Interannual Variability of Sea Surface Temperature Off Java and Sumatera in A Global GCM*. J. Climate. 21:2451-2465.doi/10.1175/2007JCLI1753.1.

Fadholi, A. 2013. Studi Dampak El Nino dan Indian Ocean Dipole (IOD) terhadap Curah Hujan di Pangkalpinang. J. IImu Lingkungan. 11(1): 4350.
Fajri, F., Rifardi, R. \& Tanjung. A. 2012. Studi Abrasi Pantai Kota Padang Provinsi Sumatera Barat. J. Perikanan dan Kelautan. 17(2):36-42.

Hong, P.C., Aweng, E.R. \& Hermansyah, H. 2012. Pollution Sources, Beneffical Uses and Management of Batang Arau and Kuranji River in Padang, Indonesia. J. Applied Sci. Environ. Sanitation. 7(3):221-230.

Kamal, E. \& Syahbuddin, S. 2003. Kajian Fisika Kimia Pelabuhan Muara Padang Menjadi Kwasan Wisata Marina. J. Mangrove dan Pesisir. 3(2):13-26.

Kwiatkowski, C., Matthias, P., Vidya, V., Stephan, S., Dierk H. \& Mahyar, M. 2015. Holocene Variations of Thermocline Conditions in The Eastern Tropical Indian Ocean. Qua. Sci. Rev. 114:33-42. doi: 10.1016/j.quascirev.2015.01. 028.

Natasasmita, D. 2015. Dampak Pemanasan Global dan Fenomena pengasaman laut terhadap terumbu karang. www.kompasiana.com/divera dios/54f74b50a3331137728b48c3. Accessed at $12^{\text {th }}$ April 2015 time 21.34 WIB

Parsons, T. R., Masayuki T. \& Barry, H. 1984. Biological Oceanographic Processes. Third Edition. London, Pergamon press.

Partowijoto, H.A. 2006. Monitoring and Studies on Water Quality in some Rivers Related Water Bodies in Indonesia. Indonesia Water Partnership. $24 \mathrm{hlm}$

Putri, W.A.E. 2007. Kapasitas Asimilasi Bahan Pencemar di Muara Sungai Batang Arau (Muara Padang) Sumatera Barat. J. Akuatik. 1(1): 2734.

Putri, W.A.E. 2010. Pencemaran Bahan Organik di Muara Sungai Batang Arau Padang Sumatera Barat. J. Maspari. 01(1): 30-34.

Sanusi, H.S. 2004. Chemical Characteristic and Fertility of Pelabuhan Ratu Bay Waters at East and West Monsoon. J. IImu-IImu Perairan dan Perikanan Indonesia. 11(2): 93-100.

Sugianto, D.N., \& Anugroho, A. 2007. Studi Pola Sirkulasi Arus Laut di Perairan Pantai Provinsi Sumatera Barat. IImu Kelautan, 2(2): 79-92.

Wisha, U.J., Yusuf, M. \& Maslukah, L. 2014. Sebaran Muatan Padatan Tersuspensi dan Kelimpahan 
Fitoplankton di Perairan Muara Sungai Porong Kabupaten SIdoarjo. J. Oce. 3(3): 454-461.

Yamagata, T., Swadhin, K.B., Rao, S.A. Zhooyong, G., Karamuri, A. \& Saji, H.N. 2002. The Indian
Dipole. A physical Entity Exchanges No. 24, Southhampton, UK. 